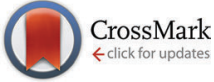

Cite this: J. Mater. Chem. C, 2015 3, 7345

Received 7th May 2015,

Accepted 12th June 2015

DOI: $10.1039 / c 5 t c 01293 g$

www.rsc.org/MaterialsC

\title{
Modulation of (non)linear optical properties in tripodal molecules by variation of the peripheral cyano acceptor moieties and the $\pi$-spacer $\dagger$
}

\author{
D. Cvejn, ${ }^{a}$ E. Michail, ${ }^{b}$ I. Polyzos, ${ }^{b}$ N. Almonasy, ${ }^{a}$ O. Pytela, ${ }^{a}$ M. Klikar, ${ }^{a}{ }^{\text {T. }}$ Mikysek, \\ V. Giannetas, ${ }^{b}$ M. Fakis ${ }^{b}$ and F. Bureš*a
}

\begin{abstract}
A series of twelve tripodal push-pull molecules with a central triphenylamine donor and peripheral cyano substituted acceptors has been prepared. These molecules possess systematically altered $\pi$-linkers as well as cyano acceptors. Based on the experimental properties measured by differential scanning calorimetry, electrochemistry, one and two photon absorption/emission spectroscopy, supported by the DFT calculations, thorough structure-property relationships were elucidated.
\end{abstract}

\section{Introduction}

Multiphoton absorbing (MPA) ${ }^{1}$ molecules are currently attracting considerable attention of organic and material chemists as well as physicists. The simultaneous absorption of two photons by a molecule has been theoretically predicted as early as 1931 by M. Göppert-Mayer and experimentally verified after the invention of the laser (1960). The fact that the excited state of a molecule can be populated by absorbing two/three photons of half/third the energy makes the two/three-photon absorption (2/3PA) a very attractive phenomenon. ${ }^{2}$ The use of a low-energy excitation source (NIR laser) along with the intensity-dependent MPA processes can be considered as two principal advantages that opened immense interest and prospective applications of MPAactive molecules across optoelectronics and photonics. ${ }^{3}$ Thus, materials exhibiting a large 2PA cross-section have been utilized in the fields ranging from materials science, biology and medicine to $2 \mathrm{PA}$ fluorescent microscopy while cellular imaging, ${ }^{4}$ photodynamic therapy, ${ }^{5}$ frequency up-converted lasing, ${ }^{6}$ 3D optical data storage, ${ }^{7}$ 3D microfabrication and lithography ${ }^{8}$ can be considered as the currently most successful applications.

A joint feature of the most successful organic molecules is their push-pull and mostly tripodal (branched, star-shaped or

\footnotetext{
${ }^{a}$ Institute of Organic Chemistry and Technology, Faculty of Chemical Technology, University of Pardubice, Studentská 573, Pardubice, 53210, Czech Republic. E-mail: filip.bures@upce.cz; Web: http://bures.upce.cz; Fax: +420 46603 7068; Tel: +420466037099

${ }^{b}$ Department of Physics, University of Patras, GR-26504, Patras, Greece

${ }^{c}$ Department of Analytical Chemistry, Faculty of Chemical Technology, University of Pardubice, Studentská 573, Pardubice, 53210, Czech Republic

$\dagger$ Electronic supplementary information (ESI) available: Synthesis of chromophores 1-5 and all intermediates 13-25, electrochemical and optical data, correlations and NMR spectra. See DOI: 10.1039/c5tc01293g
}

octupolar) arrangement. In a push-pull $\mathrm{D}-\pi-\mathrm{A}$ molecule (D = electron donor, $\pi=$ conjugated system and $\mathrm{A}=$ electron acceptor), an intramolecular charge transfer (ICT) from the donor via the $\pi$-system to the acceptor occurs and the molecule becomes polarized and constitutes a dipole. The $\mathrm{D}-\mathrm{A}$ interaction results in the formation of a new molecular orbital in which facile electron excitation by visible light takes place. Hence, push-pull molecules are also called chromophores. ${ }^{9}$ Apart from $N, N$-dialkylamino groups used as ordinary donors in linear $\mathrm{D}-\pi-\mathrm{A}$ systems, triphenylamine (TPA) proved to be a very useful and readily available precursor for the synthesis of tripodal molecules. The central amino donor in TPA can easily be connected to various peripheral acceptors to gain $\mathrm{D}(-\pi-\mathrm{A})_{3}$ push-pull systems. In fact, $\mathrm{D}(-\pi-\mathrm{A})_{3}$ systems are much thoroughly investigated than inverse $\mathrm{A}(-\pi-\mathrm{D})_{3}$ molecules $^{10}$ which is most likely due to their tedious and limited synthesis compared to possible modifications of the parent TPA (Fig. 1).

The vast majority of tripodal molecules have been built on TPA and, since late 90s, an admirable number of articles reporting their preparation and 2PA activity have been published. ${ }^{11}$ These $\mathrm{D}(-\pi-\mathrm{A})_{3}$ molecules possess peripheral electron withdrawing groups such as nitro, ester, carbonyl, trifluoromethylsulfonyl etc. as well as
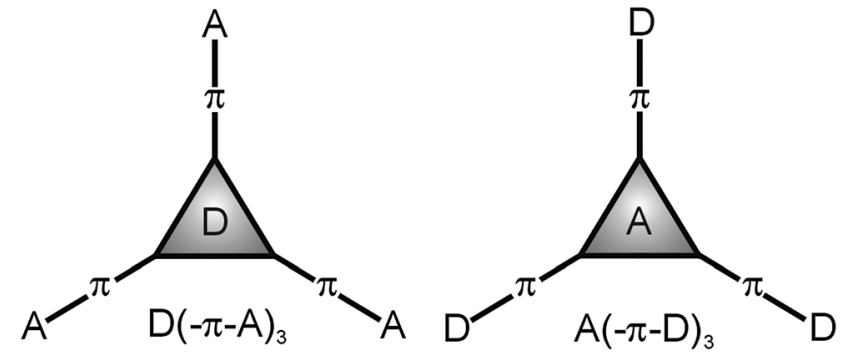

Fig. 1 Two principal arrangements of tripodal push-pull molecules. 
(hetero)aromatic moieties such as fluorene, perylene diimide, dimesitylboryl, pyridine/pyridinium, triazole, oxadiazole, benzothiazole, benzothiadiazole and porphyrin. Some dendritic molecules have recently appeared as well. ${ }^{12}$ Further applications of such TPA-derived push-pull molecules range from 3PA, ${ }^{13}$ organic solar cells, ${ }^{14}$ molecular glasses, ${ }^{15}$ intercalates and metal-organic frameworks (MOF) ${ }^{16}$ to sensors used for the detection of ions, ${ }^{17}$ amines ${ }^{18}$ and explosives. ${ }^{19}$ In contrast to linear D- $\pi-\mathrm{A}$ systems, ${ }^{9,20}$ less tripodal compounds bearing peripheral cyano-substituted acceptor moieties were prepared and investigated as 2PA-active substances to date. ${ }^{21}$ Besides their exceptional 2PA activity, a few cyano-substituted TPA molecules were also utilized in solar cells. ${ }^{22}$

As only a few comprehensive structure-property relationship studies on tripodal TPA molecules were reported to date ${ }^{23}$ and as an extension of our recent efforts in the field of property tuning in push-pull molecules, ${ }^{9 a}$ we report herein on the design, synthesis and further studies of twelve model $\mathrm{D}(-\pi-\mathrm{A})_{3}$ molecules 1-12 (Fig. 2). These chromophores possess either one or two cyano groups connected to each particular TPA branch and vary in the arrangement, extension and composition of the $\pi$-linker. The impacts of such structural changes on the properties of 1-12 were studied by means of differential scanning calorimetry, electrochemistry, one and two photon absorption spectroscopy and were also supported by DFT calculations.

\section{Results and discussion}

\section{Synthesis}

In general, the synthesis of chromophores 1-12 involves three reaction steps: synthesis of the properly substituted TPA derivative, preparation of the acceptor moieties and their final combination via a cross-coupling reaction. Schemes 1 and 2 show the preparation of the particular D- and A-parts 13-16 and 23-33, respectively. Threefold Sonogashira cross-coupling of commercially available tris(4-iodophenyl)amine 13 with an excess of trimethylsilylacetylene (TMSA) and subsequent TMS group removal by tetrabutylammonium fluoride (TBAF) afforded smoothly tris(4-ethynylphenyl)amine 14 in 76\% overall yield. ${ }^{23 c}$ A similar threefold Sonogashira reaction using propargyl alcohol afforded triole $\mathbf{1 5}$ which upon oxidation with the Dess-Martin reagent provided trialdehyde 16. The synthesis of $\mathbf{1 6}$ can also be accomplished via a Sonogashira reaction of $\mathbf{1 3}$ with 3,3-diethoxypropyn affording triacetal 34 (90\%). Subsequent removal of the acetal protecting group afforded 16 in $61 \%$ yield. However, the overall yield is generally lower than that attained via the reaction path shown in Scheme 1 (see the $\mathrm{ESI} \dagger$ for more details). The synthesis of di- and tricyanosubstituted benzenes 23-25 (Scheme 2) has been accomplished in a modular manner starting from di- and trimethylbromobenzenes which were oxidized to corresponding acids 17-19 using $\mathrm{KMnO}_{4}$ in $t \mathrm{BuOH}$ and subsequently treated with thionyl chloride and saturated with gaseous $\mathrm{NH}_{3}$ to afford amides 20-22. This conversion for $\mathbf{1 9}$ was accompanied by a halogen replacement and, therefore, chlorotriamide 22 was isolated instead of the expected bromotriamide. Final dehydration to nitriles 23-25 was carried out by trifluoroacetic anhydride (TFAA) in dioxane/pyridine. Other precursors of the electron withdrawing moieties in 1-12 are also shown in Scheme 2. They are either commercially available (26-28, 30 and 32 ) or can easily be synthesized via procedures reported in the literature (29 and 31). ${ }^{24,25}$ 2-Iodothiophene-3,4-dicarbonitrile 33 was synthesized via a selective

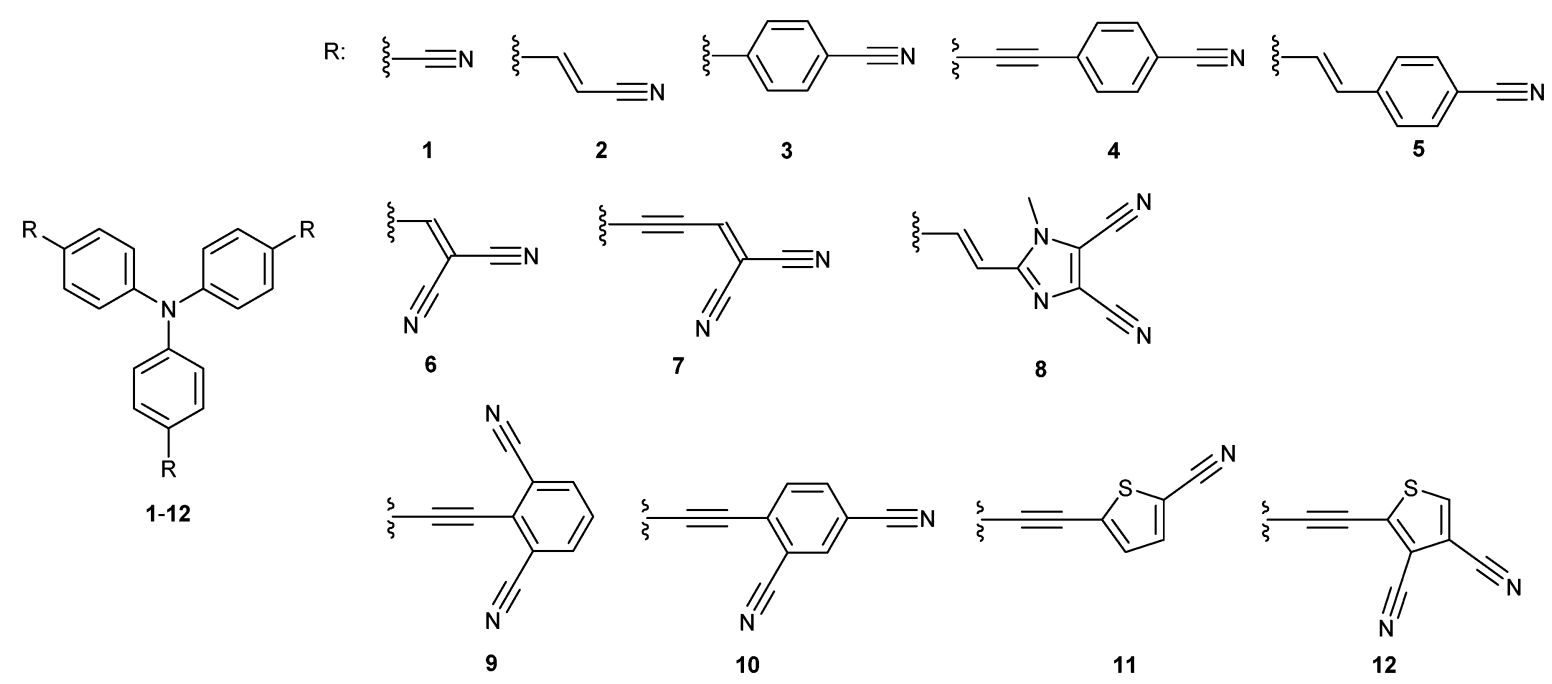

Fig. 2 Molecular structure of all target chromophores 1-12.

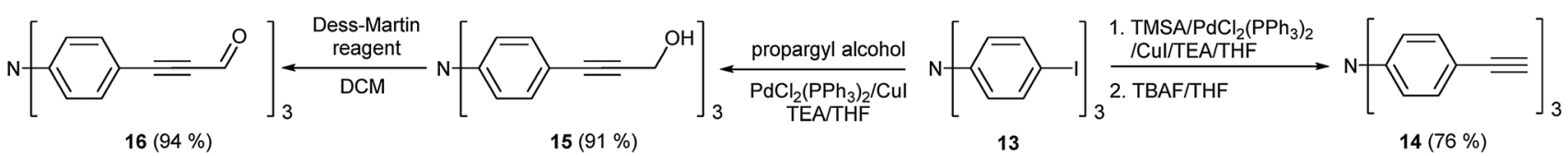

Scheme 1 Modification of the TPA core leading to precursors 13-16 


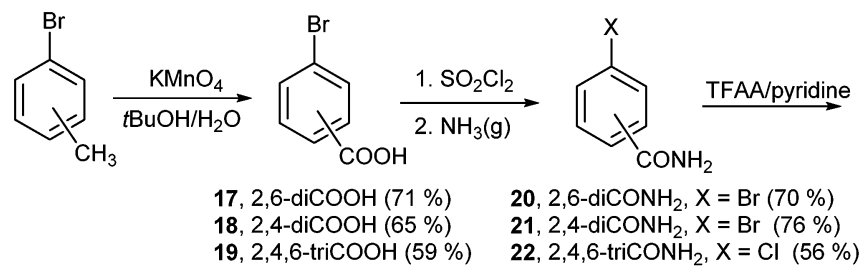<smiles>N#Cc1cccc(C#N)c1Br</smiles><smiles>C#CC#Cc1ccc(C#N)cc1</smiles><smiles>N#Cc1ccc(/C=C/c2ccccc2)cc1</smiles><smiles>C=Cc1nc(C#N)c(C#N)n1C</smiles><smiles>N#Cc1csc(I)c1C#N</smiles><smiles>N#Cc1cscc1C#N</smiles>

Scheme 2 Structure and selected synthesis of cyano-substituted acceptor moieties 23-33.

monoiodination of thiophene-3,4-dicarbonitrile which was achieved by lithiation at $-78{ }^{\circ} \mathrm{C}$ and a subsequent reaction with molecular iodine. ${ }^{26}$

The synthetic details and spectral characterization of precursors and intermediates 14-25 are given in the ESI. $\dagger$ Target tripodal push-pull molecules 1-12 were obtained by a combination of the aforementioned A- and D-precursors, mainly in terms of crosscoupling reactions as shown in Scheme 3 . Threefold cyanation ${ }^{27}$ of triiodotriphenylamine proved to be tedious and, therefore, chromophore 1 was synthesized from trialdehyde 35 (ref. $4 g$ ) by a one-pot reaction with hydroxylamine and subsequent Beckmann rearrangement. ${ }^{28}$ Chromophore 2 was prepared by Heck-Mizoroki cross-coupling reaction of $\mathbf{1 3}$ and acrylonitrile $\mathbf{2 6}$ with a similar outcome as described by Tian et al. ${ }^{29}$ The biphenyl $\pi$-linker in chromophore 3 has been generated by the Suzuki-Miyaura reaction between 13 and boronic acid 27 (76\%).

A Sonogashira reaction of $\mathbf{1 3}$ and terminal acetylene $\mathbf{2 8}$ provided chromophore $\mathbf{4}$ in generally lower yield than reported by Ogilby et al. (69 vs. 94\%). ${ }^{5 d}$ The synthesis of chromophore 5 has been described by Cho et al. via a Horner-WadsworthEmmons reaction. ${ }^{21 b}$ However, the Suzuki-Miyaura crosscoupling on 13 using boronic acid pinacol ester 29 delivered 5 in a slightly improved yield of $76 \%$. $\mathrm{Al}_{2} \mathrm{O}_{3}$-catalyzed Knoevenagel condensation $^{30}$ of aldehydes 35/16 and malononitrile 30 afforded smoothly target chromophores 6 and 7 with dicyanovinyl (DCV) moieties in the yields of 42 and 94\%. Chromophore 6 has also been previously synthesized by the pyridine/acetic acid-catalyzed condensation in a similar yield. ${ }^{11,31}$ Target chromophore 8 bearing

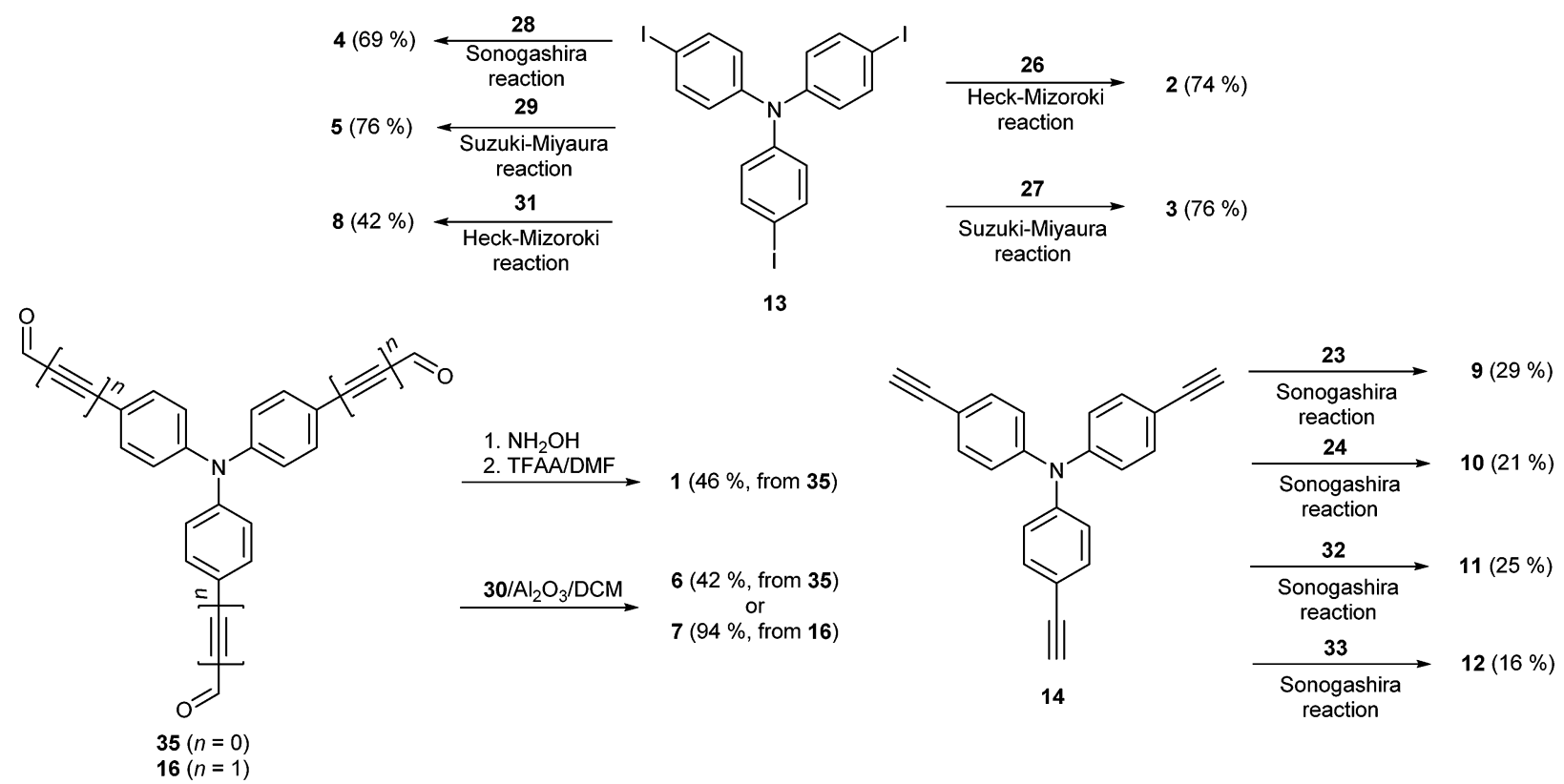

Scheme 3 Combination of A- and D-parts leading to tripodal push-pull molecules 1-12. 
peripheral dicyanoimidazole (DCI) acceptor moieties was prepared by Heck-Mizoroki olefination of $\mathbf{1 3}$ and vinazene 31. Although carried out under optimized conditions (dioxane, elevated temperature and $\operatorname{Pd}(0)$ precatalyst), a Sonogashira reaction of triacetylene 14 and halogenated dinitriles 23 and 24 afforded chromophores $\mathbf{9}$ and $\mathbf{1 0}$ only in modest yields. This reaction was complicated by the predominant formation of one- and two-fold cross-coupling products which were tedious to separate and to suppress even in the case of an excess of 23 and 24. Moreover, a similar Sonogashira reaction with trinitrile $\mathbf{2 5}$ proved to be unsuccessful at all, which is most likely caused by the presence of chloro instead of bromo substituents (see above). Cross-coupling reactions with thiophene analogues $\mathbf{3 2}$ and $\mathbf{3 3}$ afforded chromophores $\mathbf{1 1}$ and 12 in similar modest yields of 25 and 16\%, respectively.

\section{Thermal properties}

Thermal behaviour of compounds 1-12 was studied by differential scanning calorimetry (DSC). Fig. 3 shows thermograms of representative compounds 2 and $\mathbf{9}$ while Table 1 lists the measured melting temperatures $\left(T_{\mathrm{m}}\right)$ and temperatures of thermal decompositions $\left(T_{\mathrm{d}}\right)$.

The measured melting points of 1-12 range from 84 to $343{ }^{\circ} \mathrm{C}$. The temperature of decomposition was estimated

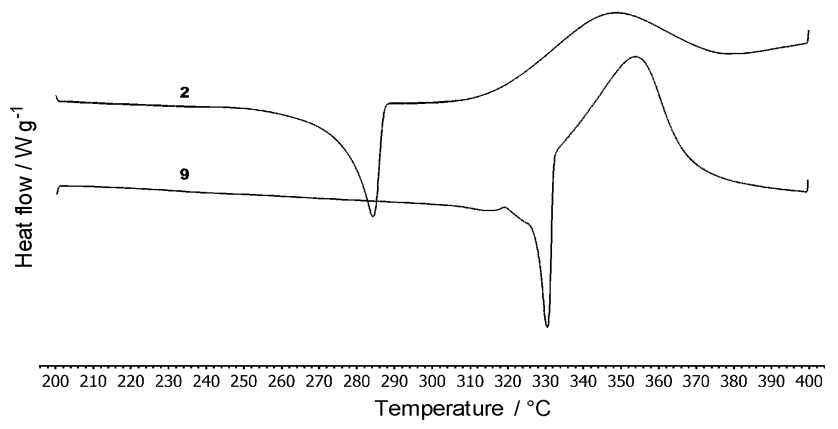

Fig. 3 Representative DSC curves of compounds 2 and 9 determined with a scanning rate of $3{ }^{\circ} \mathrm{C} \mathrm{min}^{-1}$ under $\mathrm{N}_{2}$. within the range of $176-477^{\circ} \mathrm{C}$. Compound 1 provided a very sharp peak of melting/crystallization at 343/263 ${ }^{\circ} \mathrm{C}$ and does not undergo decomposition until its boiling point $\left(436{ }^{\circ} \mathrm{C}\right)$. Thermal behaviour of compounds 2, 3, 5-9 and 11-12 is very similar with the melting point peak followed by a subsequent decomposition at a higher temperature. Compound 4 showed a wide enantiotropic solid-solid transition $\left(37-82{ }^{\circ} \mathrm{C}\right)$, melting point at $217{ }^{\circ} \mathrm{C}$ and surprisingly no decomposition peak. However, the sample was clearly carbonized after heating up to $500{ }^{\circ} \mathrm{C}$. For compound 10 , thermal decomposition preceded the melting point. As can be seen from the whole series (Table 1), DCV-terminated tripodal compounds 6 and 7 showed the lowest melting points and temperatures of thermal decompositions. TPA derivatives substituted with cyanoaromates 3-5 and 9-10 resisted thermal decomposition above $300{ }^{\circ} \mathrm{C}$. Heterocyclic acceptor moieties such as DCI and (di)cyanothiophene as in 8 and 11-12 bring also noticeable thermal stability up to $366{ }^{\circ} \mathrm{C}$, especially for the imidazole-terminated compound 8 . The measured DSC data of compounds 1-12 reflect their different molecular structure (varied peripheral acceptors and $\pi$-linkers). The following relations can be deduced from the DSC measurements:

- The melting temperatures within the most evaluated subseries of compounds 1-5 are mostly affected by an insertion of multiple bonds. In general, chromophores bearing triple bond proved less stable than the corresponding olefinic derivatives (e.g. 4 vs. 3 and 5 vs. 3 ).

- This can be further demonstrated by the DCV acceptor linked to the TPA core via an acetylenic spacer in 7, which lowered the thermal stability very significantly when compared to $6\left(\Delta T_{\mathrm{m}}=61{ }^{\circ} \mathrm{C}, \Delta T_{\mathrm{d}}=146{ }^{\circ} \mathrm{C}\right)$.

- Chromophores bearing benzene-derived acceptors (e.g. 4 or 9/10) are generally more thermally stable than the corresponding thiophene derivatives (e.g. 11 and 12).

- Chromophore 8 with the imidazole-based acceptor (DCI) showed the highest thermal resistance among all heterocyclic compounds $(\mathbf{8}, \mathbf{1 1 - 1 2})$ with $T_{\mathrm{d}}=366^{\circ} \mathrm{C}$.

Table 1 Summarized properties of chromophores 1-12

\begin{tabular}{|c|c|c|c|c|c|c|c|c|c|c|c|c|}
\hline Comp. & $\begin{array}{l}T_{\mathrm{m}}{ }^{a} \\
\left({ }^{\circ} \mathrm{C}\right)\end{array}$ & $\begin{array}{l}T_{\mathrm{d}}^{b} \\
\left({ }^{\circ} \mathrm{C}\right)\end{array}$ & $\begin{array}{l}E_{1 / 2(\mathrm{ox} 1)^{c}} \\
(\mathrm{~V})\end{array}$ & $\begin{array}{l}E_{1 / 2(\text { red } 1)^{c}} \\
\text { (V) }\end{array}$ & $\begin{array}{l}\Delta E^{c} \\
(\mathrm{~V})\end{array}$ & $\begin{array}{l}E_{\text {HOMO }}{ }^{e} \\
(\mathrm{eV})\end{array}$ & $\begin{array}{l}E_{\text {LUMO }}{ }^{e} \\
(\mathrm{eV})\end{array}$ & $\begin{array}{l}\lambda_{\max }^{\mathrm{A} f} \\
\left(\mathrm{~nm} \mathrm{eV}^{-1}\right)\end{array}$ & $\begin{array}{l}\lambda_{\max }^{\mathrm{F} \quad f} \\
\left(\mathrm{~nm} \mathrm{eV}^{-1}\right)\end{array}$ & $\begin{array}{l}\Phi^{\mathrm{F}} \\
(\%)\end{array}$ & $\begin{array}{l}\text { Stokes shift } \\
\left(\mathrm{cm}^{-1}\right)\end{array}$ & $\begin{array}{l}\delta_{2 \mathrm{PA}}^{g} \\
(\mathrm{GM})\end{array}$ \\
\hline 1 & 343 & - & 1.49 & -2.01 & 3.50 & -5.92 & -2.42 & $339 / 3.66$ & $377 / 3.29$ & 0.62 & 2970 & - \\
\hline 2 & 275 & 317 & 1.12 & -1.74 & 2.86 & -5.55 & -2.69 & $394 / 3.15$ & $460 / 2.70$ & 0.48 & 3640 & $260(770)$ \\
\hline 3 & 329 & 340 & 1.02 & -2.02 & 3.04 & -5.45 & -2.41 & $372 / 3.33$ & $448 / 2.77$ & 0.64 & 4560 & $566(760)$ \\
\hline 4 & 217 & - & 1.04 & -1.85 & 2.89 & -5.47 & -2.58 & $387 / 3.20$ & $458 / 2.71$ & 0.59 & 4010 & 785 (780) \\
\hline 5 & 291 & 477 & 0.85 & -1.80 & 2.65 & -5.28 & -2.63 & $403 / 3.08$ & $510 / 2.43$ & 0.51 & 5210 & $1100(810)$ \\
\hline 6 & 145 & 322 & 1.41 & $-^{d}$ & - & -5.84 & - & $453 / 2.74$ & $549 / 2.26$ & 0.29 & 3860 & $757(830)$ \\
\hline 7 & 84 & 176 & 1.29 & $-^{d}$ & - & -5.72 & - & $470 / 2.64$ & $611 / 2.03$ & 0.29 & 4910 & $667(810)$ \\
\hline 8 & 188 & 366 & 0.97 & -1.66 & 2.63 & -5.40 & -2.77 & $413 / 3.00$ & $497 / 2.49$ & 0.59 & 4090 & $620(810)$ \\
\hline 9 & 327 & 333 & 1.16 & -1.55 & 2.71 & -5.59 & -2.88 & $420 / 2.95$ & $533 / 2.33$ & 0.69 & 5050 & $852(810)$ \\
\hline 10 & - & 282 & 1.15 & -1.44 & 2.59 & -5.58 & -2.99 & $414 / 3.00$ & $499 / 2.48$ & 0.55 & 4126 & $631(810)$ \\
\hline 11 & 191 & 240 & 1.09 & -1.45 & 2.54 & -5.52 & -2.98 & $397 / 3.12$ & $475 / 2.61$ & 0.46 & 4140 & $148(750)$ \\
\hline 12 & 198 & 252 & 1.17 & -1.41 & 2.58 & -5.60 & -3.02 & $412 / 3.01$ & $516 / 2.40$ & 0.49 & 4890 & $375(830)$ \\
\hline
\end{tabular}

${ }^{a} T_{\mathrm{m}}=$ melting point (the point of intersection of a baseline before the thermal effect with a tangent). ${ }^{b} T_{\mathrm{d}}=$ thermal decomposition (pyrolysis in a $\mathrm{N}_{2}$ atmosphere). ${ }^{c} E_{1 / 2(\mathrm{ox} 1)}$ and $E_{1 / 2(\mathrm{red} 1)}$ are half-wave potentials of the first oxidation and reduction, respectively; all potentials are given $v s$. SCE; $\Delta E=E_{1 / 2 \text { (ox1) }}-E_{1 / 2 \text { (red1) }}{ }^{d}$ Electrode surface inhibition. ${ }^{e}-E_{\text {HOMO/LUMO }}=E_{1 / 2 \text { (ox1/red1) }}+4.429$ (ref. 32). ${ }^{f}$ Measured in THF. ${ }^{g}$ The wavelength of the maximum 2PA cross section is shown in parenthesis (measured in THF). 


\section{Electrochemistry}

Electrochemical measurements of chromophores 1-12 were carried out in acetonitrile containing $0.1 \mathrm{M} \mathrm{Bu}_{4} \mathrm{NPF}_{6}$ in a three electrode cell by cyclic voltammetry (CV), rotating disk voltammetry (RDV) and polarography. The working electrode was a platinum disk ( $2 \mathrm{~mm}$ in diameter) for CV and RDV experiments. A saturated calomel electrode (SCE) separated by a bridge filled with a supporting electrolyte and a Pt wire were used as reference and auxiliary electrodes. The acquired data are summarized in Table 1, while representative CV diagrams of compounds 5, 7-9 and 11 are given in the ESI.

The measured half-wave potentials of the first oxidation and reduction $\left(E_{1 / 2(\mathrm{ox} 1)}\right.$ and $\left.E_{1 / 2(\mathrm{red} 1)}\right)$ of chromophores 1-12 were found within the range of 0.85 to 1.49 and -1.41 to $-2.02 \mathrm{~V}$, respectively. The first reduction and oxidation are one-electron processes, followed by subsequent oxidations and reductions, and are obviously a function of the peripheral acceptor and the $\pi$-linker (Table 1). Whereas the first oxidation can be attributed to the central TPA donor, the first reduction is mostly localized on the peripheral $\mathrm{CN}$ groups and the adjacent $\pi$-system. The first oxidation potentials of chromophores 1-5 bearing monocyano-substituted acceptor moieties steadily decreased from 1.49 to $0.85 \mathrm{~V}$ as a function of the $\pi$-system elongation. The first reduction potentials showed similar trends with exception for 3 in which nonplanar biphenyl $\pi$-linker allows only reduced ICT. The difference between the first oxidation and reduction potentials (electrochemical gap, $\Delta E$ ) represents a straightforward way for the evaluation of the ICT. When going from $1(\Delta E=3.50 \mathrm{~V})$ to $2(\Delta E=2.86 \mathrm{~V})$, the electrochemical gap decreased by $0.64 \mathrm{~V}$, as a consequence of the insertion of an additional olefinic subunit. However, further $\pi$-system extension as in 3 resulted in an increased gap of $3.04 \mathrm{~V}$. This demonstrates "ICT transparency" of the olefinic unit in comparison to the aromatic 1,4-phenyl moiety. ${ }^{33}$ Further extension and planarization of the $\pi$-linker by acetylenic and olefinic subunits (3 vs. 4 and 5) lowered the electrochemical gap up to $2.65 \mathrm{~V}$. Dicyanosubstituted (hetero)aromatic moieties attached to the TPA core affected both the first oxidation and the reduction potentials (8-12, Table 1). The evaluation of the ICT based on the overall electrochemical gap $\Delta E$ implies that these (hetero)aromates impart a stronger resonance effect than aromates ( $\Delta E$ of 2.712.54 vs. 3.50-2.65 V for 1-5 vs. 8-12). Positioning of the $\mathrm{CN}$ groups along the (hetero)aromatic scaffold plays also a significant role as can be seen for instance on chromophores $\mathbf{9}$ and 10. The latter, 2,4-dicyano-substituted chromophore showed a reduced gap by $0.12 \mathrm{~V}$. The lowest electrochemical gap $(\Delta E=2.58 \mathrm{~V})$ was measured for chromophore 11 bearing a cyano-acceptor based on polarizable thiophene with the cyano group attached at the resonant and most extended C5 position (as compared to the dicyano acceptor in 12). A comparison of chromophores 4 and 11 also allows comparison of 1,4phenylene and 2,5-thienylene $\pi$-systems. ${ }^{34}$ With very similar oxidation potentials (1.04 and $1.09 \mathrm{~V})$, the latter showed significantly lowered first reduction potential $(-1.45 \mathrm{vs} .-1.85 \mathrm{~V})$ as well as the electrochemical gap $(\Delta E=2.89 v s .2 .54 \mathrm{~V})$.

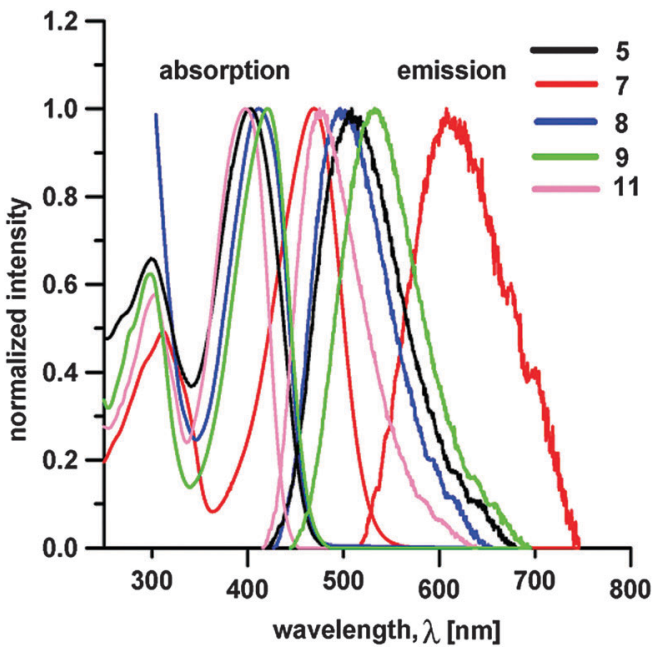

Fig. 4 Representative absorption (left) and fluorescence (right) spectra of chromophores 5, 7-9 and $\mathbf{1 1}$ measured in THF.

\section{One photon absorption and emission}

Target chromophores are coloured molecules, their colours range from yellowish to red (see the ESI $\dagger$ ). Optical properties of 1-12 were investigated by electronic absorption and emission spectra; the longest-wavelength absorption/emission maxima $\lambda_{\text {max }}^{\mathrm{A}} / \lambda_{\text {max }}^{\mathrm{F}}$, the fluorescence quantum yields $\Phi^{\mathrm{F}}$ and the Stokes shifts are summarized in Table 1 . Fig. 4 shows absorption and emission spectra of representative chromophores 5, 7-9 and 11.

Whereas the absorption maxima range from 339 to $470 \mathrm{~nm}$, the emission maxima are red-shifted to $377-611 \mathrm{~nm}$. The absorption spectra are dominated by one intense CT-band whose position is clearly dependent on the nature of the appended cyano-acceptors and the $\pi$-system. When considering the monocyano-substituted series of molecules $\mathbf{1 - 5}$, the $\lambda_{\max }^{\mathrm{A}}$ values showed a very similar trend as seen for the electrochemical gaps $\Delta E$. Namely, extension of the $\pi$-system by olefinic (1 vs. 2) or aromatic units (3vs. 2), planarization (4/5 vs. 3) and further elongation by acetylenic subunit (4) affected the absorption maxima within the range of 339 to $403 \mathrm{~nm}$. It should be noted that the longest-wavelength absorption maxima of 1-12 correlate very tightly with the measured electrochemical gap $\Delta E$ (see the ESI $\dagger$ ). Chromophores 6 and 7 bearing strong electron DCV acceptors showed the most bathochromically shifted CT-bands with $\lambda_{\text {max }}^{\mathrm{A}}$ at 453 and $470 \mathrm{~nm}$, respectively. In contrast to 1-5, chromophores 8-10 and 12 exhibited red-shifted absorption maxima up to $412-420$ as a result of the appended dicyanosubstituted (hetero)aromatic acceptor moieties. However, the differences in $\lambda_{\max }^{\mathrm{A}}$ are just within the range of $8 \mathrm{~nm}$, which implies that, in contrast to electrochemical gap, the central (hetero)aromatic $\pi$-system and positioning of the $\mathrm{CN}$ groups do not affect the absorption properties very significantly.

The fluorescence spectra exhibited one single band with $\lambda_{\max }^{\mathrm{F}}$ appearing at $377-611 \mathrm{~nm}$. In general, its position is affected by the same structural features as the aforementioned absorption bands. Both positions of the longest-wavelength absorption and fluorescence maxima showed tight correlations (see the ESI $\dagger$ ). 
The quantum yields lie within the range of 0.29 to 0.69 . The lowest quantum yields were measured for chromophores 6 and 7 with strongly electron withdrawing DCV moieties. The weaker (di)cyano acceptors in 1-5 and 8-12 lead generally to blue-shifted emission with a high quantum yield. This is in accordance with our previous observations on linear and X-shaped push-pull molecules with strong or weak ICT. ${ }^{20 g, h, 33 a}$

\section{Two photon absorption}

The 2PA properties of tripodal chromophores 1-12 were studied by means of two-photon excited fluorescence spectroscopy within the spectral range from 750 to $850 \mathrm{~nm}$. The advantage of this method is that low concentrations are used and that the order of the non-linear effect is monitored by detecting the intensity of the emitted fluorescence as a function of excitation power. In the case of two-photon excitation, the emitted fluorescence is dependent on the square of the excitation laser power. This was checked in all experiments to confirm the 2PA process. The excitation power was in all cases kept below $20 \mathrm{~mW}$ in order to minimize thermal effects and in most cases the $2 \mathrm{PA}$ cross-sections were measured within the range of 10-20 mW. The samples were $10^{-4} \mathrm{M}$ solutions of the dyes in THF. The contribution of the solvent was taken into account by subtracting the intensity of scattered light, obtained by a cuvette containing the solvent only, from the measurements. The two-photon absorption cross-sections were determined by using Rhodamine B in methanol $\left(10^{-4} \mathrm{M}\right.$ concentration), as reference.

The 2PA spectra of all compounds, i.e. the 2PA cross-sections $\left(\delta_{2 \mathrm{PA}}\right)$ as a function of excitation wavelength, are shown in Fig. 5. For a better comparison of the 2PA properties, target chromophores 1-12 were split into four groups according to the peripheral acceptor moieties. Whereas the first group includes chromophores 2-5 with monocyano acceptors, chromophores 6 and 7 in the second group possess DCV acceptors. The third and fourth group of molecules consist of dicyano aromatic (9 and 10) and (di)cyano heteroaromatic acceptor moieties $(\mathbf{8}, \mathbf{1 1}-\mathbf{1 2})$, respectively. In all cases, good 2PA properties were observed with the 2PA cross-section exceeding $1000 \mathrm{GM}$ for compound 5. In general, chromophores 4 and 5 with monocyano acceptors displayed a larger 2PA cross section than the other tripodal molecules in the whole series. Moreover, these two chromophores also exhibited good fluorescence quantum yields $(>0.50)$. The 2PA results are summarized in Table 1 .

Fig. 5 a compares the 2PA spectra of mono-cyano terminated chromophores 2-5 and 11. Compound $\mathbf{1}$ showed negligible 2PA cross-section within the investigated spectral area. It was observed that by increasing the length of the $\pi$-linker, i.e. passing from 2 to 4 and 5 , the 2PA cross sections increased. In addition, it is also obvious that upon changing the acetylenic $\pi$-conjugated bridge by an olefinic one ( $4 v s .5$ ), the $2 \mathrm{PA}$ crosssections significantly increased up to $1100 \mathrm{GM}$ (at $810 \mathrm{~nm}$ ) for 5 while this is $785 \mathrm{GM}$ (at $780 \mathrm{~nm}$ ) for 4 . Since the fluorescence quantum yields of $\mathbf{4}$ and $\mathbf{5}$ are similar (Table 1), the 2PA action cross-section product $\Phi \times \delta_{\text {TPA }}$ is again higher for $\mathbf{5}$ than for $\mathbf{4}$. This renders molecule $\mathbf{5}$ as a promising candidate for upconverted lasing or two-photon imaging. A replacement of the
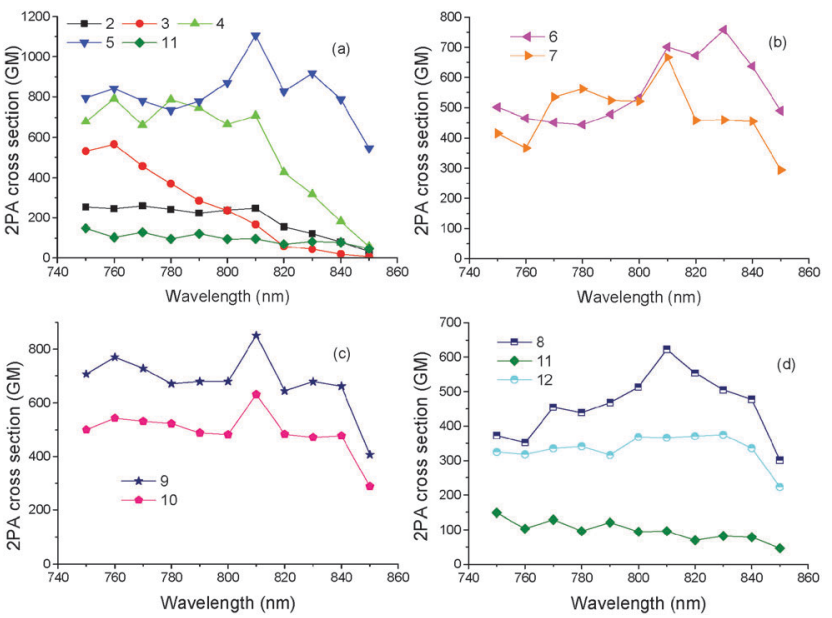

Fig. 5 Two-photon absorption cross-sections, $\delta_{2 \mathrm{PA}}$, of (a) 2, 3, 4, 5 and 11 (b) 6 and 7 (c) 9 and 10 and (d) 8, 11, 12. All compounds have been measured in THF solutions at $10^{-4} \mathrm{M}$ concentration.

1,4-phenylene moiety in 4 with 2,5-thienylene one (11) led to more than seven-times decrease of the 2PA cross sections (Table 1, 1100 vs. $148 \mathrm{GM}$ ). Hence, heteroaromatic polarizable moiety based on thiophene in $\mathbf{1 1}$ did not bring the expected higher 2PA activity. Another conclusion drawn from Fig. 5a is that the peaks of the 2PA spectra appear at approximately twice the wavelengths of the one photon absorption spectra. This is in accordance with the two-photon allowed states for octupolar molecules. Specifically, the 2PA spectrum of 4 is blue-shifted compared to $\mathbf{5}$ while that of $\mathbf{3}$ is blue shifted compared to $\mathbf{2}$ as in the case of their one-photon absorption spectra.

The 2PA spectra of chromophores 6 and 7 bearing the strongest DCV acceptor are shown in Fig. 5b. Chromophore 6 exhibited a large 2PA cross-section of $760 \mathrm{GM}$ at $830 \mathrm{~nm}$. Interestingly, an extension of the $\pi$-conjugated path by an additional acetylene subunit as in 7 did not lead to enhanced 2PA cross-sections. The fluorescence quantum yields of 6 and 7 are relatively low making the $\Phi \times \delta_{2 \mathrm{PA}}$ values significantly smaller than those of compounds 4 and 5. However, it should be noted that, according to their one-photon absorption spectra, the maximum of the 2PA spectra of 6 and 7 is expected at wavelengths close to $900 \mathrm{~nm}$, which are not covered by our experiment. On the other hand, chromophore 6 with a DCV acceptor exhibited much larger 2PA cross-section than structurally related 2 , which possesses only one cyano group.

Fig. $5 \mathrm{c}$ presents the 2PA cross-sections of $\mathbf{9}$ and $\mathbf{1 0}$ bearing dicyano aromatic acceptors with different orientation of the appended $\mathrm{CN}$ groups. The position of the cyano groups played significant role as 9 exhibited an approximately 1.35-times larger 2PA cross-sections compared to 10. Moreover, the fluorescence quantum yield is higher for $9(0.69)$ compared to 10 (0.55), which provides 9 a larger $\Phi \times \delta_{2 \mathrm{PA}}$ value. A comparison of the structurally related chromophores 10 and $\mathbf{4}$, with di- and monocyano aromatic acceptor moieties, reveals that the second cyano group has broadened and red-shifted the 2PA spectra. This is in accordance with one photon absorption spectra, but, on the other hand, it also causes a decrease of the 2PA response. 
Finally, the 2PA cross-sections of chromophores 8, 11 and $\mathbf{1 2}$ with (di)cyano-heteroaromatic acceptors are compared in Fig. 5d. Chromophores $\mathbf{1 1}$ and $\mathbf{1 2}$ with thiophene acceptors exhibited relatively small $2 \mathrm{PA}$ cross-section values compared to their analogues $\mathbf{4}$ and $\mathbf{1 0}$ having a phenyl ring. Thus, a replacement of 1,4-phenylene by 2,5-thienylene moieties coupled either to cyano or dicyano groups is not a useful strategy towards increasing the 2PA activity in TPA-derived tripodal chromophores. This is in contrast to general trends observed for second order NLO chromophores. ${ }^{34}$ However, an addition of the second cyano group into $\mathbf{1 1}$ leads to $\mathbf{1 2}$ with more than three-times higher 2PA cross-section without affecting the florescence quantum yield. This makes the thiophene substituted chromophores $\mathbf{1 1}$ and $\mathbf{1 2}$ extremely sensitive to the number of cyano groups. On the other hand, 2PA crosssections measured for the analogous chromophores 4 and $\mathbf{1 0}$ with 1,4-phenylene parent moieties showed less sensitivity. Chromophore $\mathbf{8}$ bearing three peripheral DCI acceptor units exhibited a relative large 2PA cross-section of $620 \mathrm{GM}$ at $810 \mathrm{~nm}$ accompanied by a good quantum yield of 0.59 . Although, a straightforward comparison of the 2PA properties of the herein studied compounds with literature data is not easy because of various experimental approaches used (sample concentration, solvent used, pulse duration, laser power, spectral range etc.), chromophores $\mathbf{4}$ and $\mathbf{5}$ are found to exhibit similar or better 2PA activity compared with other tri-branched compounds with $\mathrm{D}(-\pi-\mathrm{A})_{3}$ arrangement and similar molecular weight. ${ }^{11 b, h}$

\section{Quantum chemical calculations}

The spatial and electronic properties of the parent TPA and chromophores 1-12 were investigated using the Gaussian W09 package $^{35}$ at the DFT level. The initial geometries of molecules 1-12 were estimated using the PM3 method implemented in ArgusLab $^{36}$ and these were subsequently optimized using the DFT B3LYP/6-311++G(2d,p) method. The energies of the HOMO and LUMO, their differences and ground state dipole moments were calculated with the DFT B3LYP/6-311++G(2d,p) and are summarized in Table 2.

The calculated energies of the HOMO/LUMO of 1-12 range from $-6.76 /-3.81$ to $-5.62 /-2.39 \mathrm{eV}$ and are obviously a function

Table 2 DFT calculated properties ${ }^{a}$ of TPA and chromophores 1-12

\begin{tabular}{lllllr}
\hline Comp. & Symmetry group & $E_{\text {Hомо }}{ }^{a}(\mathrm{eV})$ & $E_{\mathrm{LUMO}}{ }^{a}(\mathrm{eV})$ & $\Delta E(\mathrm{eV})$ & $\mu(\mathrm{D})$ \\
\hline $\mathbf{T P A}$ & $D_{3}$ & -5.29 & -0.90 & 4.39 & 0.024 \\
$\mathbf{1}$ & $D_{3}$ & -6.53 & -2.53 & 4.00 & 0.000 \\
$\mathbf{2}$ & $C_{3}$ & -6.14 & -2.90 & 3.24 & 0.227 \\
$\mathbf{3}$ & $D_{3}$ & -5.86 & -2.39 & 3.47 & 0.002 \\
$\mathbf{4}$ & $D_{3}$ & -5.80 & -2.67 & 3.13 & 0.001 \\
$\mathbf{5}$ & $C_{3}$ & -5.62 & -2.75 & 2.87 & 0.221 \\
$\mathbf{6}$ & $C_{3}$ & -6.76 & -3.80 & 2.94 & 5.675 \\
$\mathbf{7}$ & $C_{3}$ & -6.49 & -3.81 & 2.68 & 7.199 \\
$\mathbf{8}$ & $C_{3}$ & -6.30 & -3.01 & 3.29 & 7.603 \\
$\mathbf{9}$ & $D_{3}$ & -5.78 & -2.84 & 2.94 & 0.035 \\
$\mathbf{1 0}$ & $C_{3}$ & -6.05 & -3.17 & 2.88 & 6.034 \\
$\mathbf{1 1}$ & $C_{3}$ & -5.81 & -2.82 & 2.99 & 5.199 \\
$\mathbf{1 2}$ & $C_{3}$ & -6.07 & -3.13 & 2.94 & 11.914 \\
& & & & &
\end{tabular}

${ }^{a}$ Calculated at the DFT B3LYP/6-311++G(2d,p) level. of the structure of the particular chromophore. Both energies correlate tightly with the experimental data obtained by the electrochemical measurements (Table 1). Hence, the used DFT method can be considered as a reasonable tool for the description of electronic properties of 1-12 (see the ESI $\dagger$ ). When going from parent TPA to molecule 1, the HOMO-LUMO gap decreased from 4.39 to $4.00 \mathrm{eV}$ as a result of attaching three cyano groups and generating a push-pull system. Further extension of the $\pi$-system within the series 1-5 affected the HOMO and LUMO levels as well as the gap in very similar way as observed by the electrochemistry. The lowest HOMO-LUMO gap within this subseries has been calculated for 5 bearing a cyano-substituted styryl linker. Further attachment of an additional CN group (4 vs. 9 and 10) resulted in drop of the calculated gap from 3.13 to 2.94 and $2.88 \mathrm{eV}$. DCV acceptors in chromophores 6-7 impart also strong ICT and reduce the gaps up to 2.94 and $2.68 \mathrm{eV}$, respectively. A replacement of the terminal 1,4-phenylene moiety in $\mathbf{4}$ by 2,5-thienylene one in $\mathbf{1 1}$ slightly decreases the HOMO-LUMO gap from 3.13 to $2.99 \mathrm{eV}$ in a similar way as observed by CV measurements. In general, both experimental and calculated HOMO-LUMO gaps correlate tightly as shown in the ESI. $\dagger$

The calculated ground state dipole moments are almost zero for molecules having the D3 group of symmetry, whereas noticeable values were obtained for molecules 6-8 and 10-12
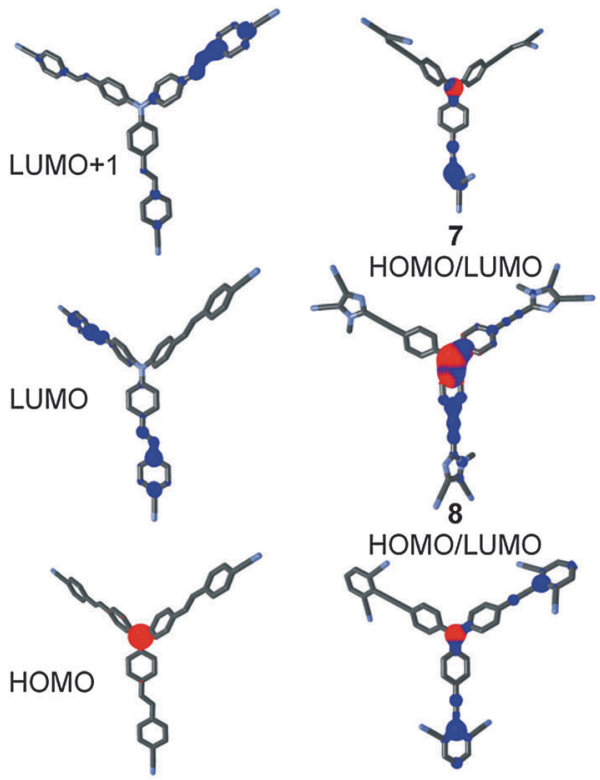

9
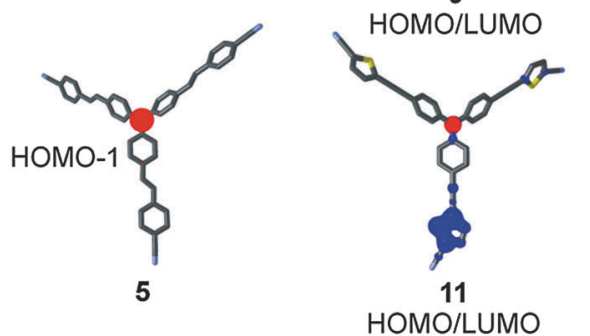

Fig. $6 \mathrm{HOMO} / \mathrm{HOMO}-1$ (red) and LUMO/LUMO+1 (blue) localizations in 5 and HOMO/LUMO mix in 7-9 and $\mathbf{1 1}$ 
having branched and unsymmetrical acceptor moieties (DCV, DCI, 2,4-dicyanobenzene and 5(2,4)-(di)cyanothiophene).

The HOMO and LUMO localizations in representative chromophores 5, 7-9 and 11 are shown in Fig. 6. For complete listing see the ESI. $\dagger$ As expected, the HOMO is localized on the central amino donor and adjacent alternating positions of the TPA, whereas the LUMO is spread over the peripheral cyano acceptor and the adjacent $\pi$-linker. Fig. 6 shows a clear charge separation and thus confirms the ICT character of chromophores 1-12. As can be seen, the LUMO is predominantly localized over one or two particular branche(s), while the third branch is occupied by the LUMO+1. The HOMO as well the HOMO-1 remained on the central amino donor. This is a common feature of tripodal molecules based on TPA. ${ }^{23 b, c, 29}$

\section{Conclusions}

A series of twelve tripodal $\mathrm{D}(-\pi-\mathrm{A})_{3}$ molecules based on triphenylamine has been designed and synthesized. The investigated push-pull systems possess one central amino donor connected via a $\pi$-linker to three peripheral cyano acceptors. Fine tuning of the properties has been achieved either by modulation of the acceptors as well as by the systematic elongation of the $\pi$-system. The synthesis has been carried out in a modular manner by connecting donor and acceptor parts via crosscoupling reactions. Target chromophores were further studied by differential scanning calorimetry, electrochemistry, one and two photon absorption and emission spectra and also quantum chemical calculations. Thorough structure-property relationships were subsequently evaluated.

Compounds 1-12 showed melting point and subsequent thermal decomposition within the range of 84-343 and 176$477^{\circ} \mathrm{C}$. These values indicate relatively high thermal resistance of TPA derived tripodal molecules.

The electrochemical properties (HOMO and LUMO levels and gap) were mainly affected by the type of peripheral acceptor, length and composition of the $\pi$-linker as well as its planarity. Using these structural changes as a tool, the electrochemical HOMOLUMO gap could be finely tuned by almost $1 \mathrm{~V}$ ( 3.50 to $2.54 \mathrm{~V}$ ).

One photon absorption and emission properties studied by electronic absorption/emission spectra revealed significant CT-bands appearing between 339/377 and 470/611 nm. Hence, optical tuning could be carried out within the range of $130 / 230 \mathrm{~nm}$. Quantum yields ranging from $0.29-0.69$ were measured for 1-12.

The two photon absorption properties of 1-12 were measured by two-photon excited fluorescence spectroscopy within the spectral range 750 to $850 \mathrm{~nm}$. A critical assessment has been carried out within/across the particular series of chromophores in order to evaluate structure-property relationships. Extension of the $\pi$-system and replacement of acetylenic by more polarizable olefinic units led to a significant increase of 2PA activity. Hence, chromophore 5 bearing a cyano substituted styryl linker showed the most enhanced NLO activity within the whole series. An attachment of aromatic acceptors bearing two $\mathrm{CN}$ groups
(9 and 10) as well as strongly withdrawing DCV units in 6 and 7 did not lead to increased $\delta_{\text {TPA }}$ coefficients compared to 5. A similar conclusion can be made for heterocyclic cyano acceptors such as DCI and 5(2,4)-(di)cyanothiophene.

HOMO and LUMO levels calculated using the DFT and their differences correlate tightly with the linear properties measured by electrochemistry and absorption/emission spectra. Considering all the aforementioned structural features of 1-12, we believe that this work could be treated as a useful guide in designing/tuning tripodal push-pull molecules with a central donor and peripheral acceptors.

\section{Experimental}

\section{Materials and methods}

For detailed description of used materials and methods used in this work see the ESI. $\uparrow$ Synthesis and full spectral characterization of target chromophores 1-5 is given in the ESI. $\dagger$ Two general methods were used for the synthesis of chromophores 6-7 and 9-12.

\section{General method for Knoevenagel condensation (chromophores} 6 and 7)

Triphenylamine-4,4 $4^{\prime}, 4^{\prime \prime}$-triscarboxaldehyde 35 (165 mg, $\left.0.5 \mathrm{mmol}\right)$ or aldehyde 16 (201 mg, $0.5 \mathrm{mmol}$ ) and malononitrile 30 (150 mg, $2.27 \mathrm{mmol}$ ) were dissolved in DCM $(20 \mathrm{ml})$ and alumina $(930 \mathrm{mg}$, $8.9 \mathrm{mmol}$, Brockmann activity II-III) was added. The reaction mixture was stirred for $4 \mathrm{~h}$ and monitored by TLC $\left(\mathrm{SiO}_{2}, \mathrm{DCM} /\right.$ EtOAc $10: 1)$. Anhydrous $\mathrm{Na}_{2} \mathrm{SO}_{4}(350 \mathrm{mg}, 2.46 \mathrm{mmol}$ ) can eventually be added to accelerate the reaction. The resulting coloured suspension was filtered and the filtrate was concentrated in vacuo. The crude products were purified by column chromatography $\left(\mathrm{SiO}_{2}, \mathrm{DCM} /\right.$ EtOAc 10:1 or DCM) to afford 6 or 7.

Chromophore 6. The title compound was synthesized from 35 and 30 following the general method for Knoevenagel condensation. Reddish-orange solid. Yield (122 mg, 42\%). $R_{\mathrm{f}} 0.3\left(\mathrm{SiO}_{2} ; \mathrm{DCM} /\right.$ EtOAc $\left.10: 1\right) \mathrm{Mp} 145{ }^{\circ} \mathrm{C}$. IR (HATR) $\nu_{\max } / \mathrm{cm}^{-1}$ 3087, $2220(\mathrm{CN}), 1559,1496,1269,1186,827 .{ }^{1} \mathrm{H}-\mathrm{NMR}: \delta_{\mathrm{H}}$ (400 MHz; $\left.\mathrm{CD}_{2} \mathrm{Cl}_{2}\right) 7.25\left(6 \mathrm{H}, \mathrm{d},{ }^{3} J\right.$ 8.8, $\left.\mathrm{CH}_{\mathrm{Ar}}\right), 7.73(3 \mathrm{H}, \mathrm{s}, \mathrm{CH}=\mathrm{C})$, $7.90\left(6 \mathrm{H}, \mathrm{d},{ }^{3} J\right.$ 8.8, $\left.\mathrm{CH}_{\mathrm{Ar}}\right) .{ }^{13} \mathrm{C}-\mathrm{NMR}: \delta_{\mathrm{C}}\left(100 \mathrm{MHz} ; \mathrm{CD}_{2} \mathrm{Cl}_{2}\right) 81.6$, 113.6, 114.7, 125.4, 128.2, 133.3, 150.7, 158.5. HR-MALDI-MS (DHB): calcd for $\mathrm{C}_{30} \mathrm{H}_{15} \mathrm{~N}_{7}\left(\mathrm{M}^{+}\right)$473.1384 found 473.1385.

Chromophore 7. The title compound was synthesized from 16 and 30 following the general method for Knoevenagel condensation. Dark red solid. Yield $96 \mathrm{mg}(94 \%) . R_{\mathrm{f}}=0.35\left(\mathrm{SiO}_{2}\right.$; $\mathrm{CH}_{2} \mathrm{Cl}_{2}$ ), M.p. $84{ }^{\circ} \mathrm{C}$. IR (HATR), $\nu_{\max } / \mathrm{cm}^{-1} 3010,2216$ (CN), 1539, 1495, 1316, 1266, 1176, 1026, 832. ${ }^{1} \mathrm{H}-\mathrm{NMR}: \delta_{\mathrm{H}}\left(400 \mathrm{MHz} ; \mathrm{CD}_{2} \mathrm{Cl}_{2}\right)$ $7.14\left(6 \mathrm{H}, \mathrm{d},{ }^{3} J\right.$ 9.0, $\left.\mathrm{CH}_{\mathrm{Ar}}\right), 7.36(3 \mathrm{H}, \mathrm{s}, \mathrm{CH}=\mathrm{C}), 7.56\left(6 \mathrm{H}, \mathrm{d},{ }^{3} J 9.0\right.$, $\left.\mathrm{CH}_{\mathrm{Ar}}\right) \cdot{ }^{13} \mathrm{C}-\mathrm{NMR}: \delta_{\mathrm{C}} \mathrm{NMR}\left(100 \mathrm{MHz} ; \mathrm{CD}_{2} \mathrm{Cl}_{2}\right)$ : 86.2, 93.0, 111.4, $112.47,114.9,115.6,124.5,135.0,140.8,148.5$. HR-MALDI-MS (DHB): calcd for $\mathrm{C}_{36} \mathrm{H}_{15} \mathrm{~N}_{7}\left(\mathrm{M}^{+}\right)$545.1384 found 545.1386.

Chromophore 8. Triiodotriphenylamine 13 (300 mg, $0.48 \mathrm{mmol})$ and 1-methyl-2-vinyl-1 $H$-imidazole-4,5-dicarbonitrile 31 (236 mg, $1.49 \mathrm{mmol})$ were dissolved in dry DMF $(5 \mathrm{ml})$ and DIPEA $(1 \mathrm{ml}$, $5.75 \mathrm{mmol}$ ). Argon was bubbled through the mixture for $10 \mathrm{~min}$, whereupon $\operatorname{Pd}\left(t-\mathrm{Bu}_{3} \mathrm{P}\right)_{2}(20 \mathrm{mg}, 0.04 \mathrm{mmol})$ was added and the 
reaction mixture was heated to $85{ }^{\circ} \mathrm{C}$ for $8 \mathrm{~h}$. The reaction mixture was poured into saturated $\mathrm{NH}_{4} \mathrm{Cl}$ solution $(100 \mathrm{ml})$ and was extracted with DCM $(2 \times 100 \mathrm{ml})$. The combined organic extracts were washed with brine $(150 \mathrm{ml})$ and water $(100 \mathrm{ml})$, dried over anhydrous $\mathrm{Na}_{2} \mathrm{SO}_{4}$ and concentrated in vacuo. The crude product was purified by column chromatography $\left(\mathrm{SiO}_{2}\right.$, EtOAc/hexane $\left.1: 3\right)$ to afford 8 as orange solid. Yield (144 mg, 42\%). $R_{\mathrm{f}} 0.4\left(\mathrm{SiO}_{2}\right.$; EtOAc/ hexane 1:3). Mp $188{ }^{\circ} \mathrm{C}$. IR (HATR), $\nu_{\max } / \mathrm{cm}^{-1} 2294,2231$ (CN), 1592, 1506, 1324, 1285, 1179, 972, 818. ${ }^{1} \mathrm{H}-\mathrm{NMR}: \delta_{\mathrm{H}}(400 \mathrm{MHz}$; $\left.\mathrm{CD}_{2} \mathrm{Cl}_{2}\right) 3.83\left(9 \mathrm{H}, \mathrm{s}, \mathrm{CH}_{3}\right), 6.77\left(6 \mathrm{H}, \mathrm{d},{ }^{3} J 16.0, \mathrm{CH}=\mathrm{CH}\right), 7.16(6 \mathrm{H}, \mathrm{d}$, $\left.{ }^{3} J 8.5, \mathrm{CH}_{\mathrm{Ar}}\right), 7.54\left(6 \mathrm{H}, \mathrm{d},{ }^{3} J 8.5, \mathrm{CH}_{\mathrm{Ar}}\right), 7.81\left(6 \mathrm{H}, \mathrm{d},{ }^{3} J 16.0, \mathrm{CH}=\mathrm{CH}\right)$. ${ }^{13} \mathrm{C}-\mathrm{NMR}: \delta_{\mathrm{C}}\left(100 \mathrm{MHz} ; \mathrm{CD}_{2} \mathrm{Cl}_{2}\right) 33.2,109.1,109.5,112.8,113.3$, $122.8,125.0,129.5,130.9,139.7,148.6,151.3$. HR-MALDI-MS (DCTB): calcd for $\mathrm{C}_{42} \mathrm{H}_{27} \mathrm{~N}_{13}\left(\mathrm{M}^{+}\right) 713.2507$ found 713.2526.

\section{General method of Sonogashira cross-coupling (chromophores} 9-12)

Tris(4-ethynylphenyl)amine $14(317 \mathrm{mg}, 1.00 \mathrm{mmol})$ and the corresponding halogen derivative $23,24,32$ or 33 (3.6 mmol) were dissolved in dry 1,4-dioxane $(40 \mathrm{ml})$ and triethylamine $(10 \mathrm{ml}$, $71.8 \mathrm{mmol}$ ). Argon was bubbled through the mixture for $10 \mathrm{~min}$, whereupon $\mathrm{Pd}\left(\mathrm{PPh}_{3}\right)_{4}(116 \mathrm{mg}, 0.10 \mathrm{mmol})$ and $\mathrm{CuI}(38 \mathrm{mg}$, $0.2 \mathrm{mmol}$ ) were added and the reaction mixture was heated to $92{ }^{\circ} \mathrm{C}$ for $8 \mathrm{~h}$. The reaction mixture was quenched with saturated solution of $\mathrm{NH}_{4} \mathrm{Cl}(150 \mathrm{ml})$ and extracted with DCM $(2 \times 150 \mathrm{ml})$. The combined organic extracts were dried over anhydrous $\mathrm{Na}_{2} \mathrm{SO}_{4}$ and concentrated in vacuo. The crude product was purified by column chromatography $\left(\mathrm{SiO}_{2}\right.$, EtOAc/hexane 2:3 or EtOAc/hexane $3: 4)$ to afford target chromophores 9-12.

Chromophore 9. The title compound was synthesized from 14 and 23 following the general method for Sonogashira crosscoupling. Dark yellow solid. Yield (204 mg, 29\%). $R_{\mathrm{f}} 0.35\left(\mathrm{SiO}_{2}\right.$; 2:3). Mp $327{ }^{\circ} \mathrm{C}$ (dec.). IR (HATR), $\nu_{\max } / \mathrm{cm}^{-1}$ 2921, 2206 (CN), 1593, 1504, 1320, 1289, 1145, 836, 801, 736. ${ }^{1} \mathrm{H}-\mathrm{NMR}: \delta_{\mathrm{H}}(400 \mathrm{MHz}$; $\left.\mathrm{CD}_{2} \mathrm{Cl}_{2}\right) 7.19\left(6 \mathrm{H}, \mathrm{d},{ }^{3} J 8.8, \mathrm{CH}_{\mathrm{Ar}}\right), 7.52\left(3 \mathrm{H}, \mathrm{t},{ }^{3} J 8.0, \mathrm{CH}_{\mathrm{Ar}}\right), 7.64(6 \mathrm{H}$, d, ${ }^{3} J$ 8.8, $\left.\mathrm{CH}_{\mathrm{Ar}}\right), 7.90\left(6 \mathrm{H}, \mathrm{d},{ }^{3} J 8.0, \mathrm{CH}_{\mathrm{Ar}}\right) \cdot{ }^{13} \mathrm{C}-\mathrm{NMR}: \delta_{\mathrm{C}}(100 \mathrm{MHz}$; $\left.\mathrm{CD}_{2} \mathrm{Cl}_{2}\right)$ 83.4, 103.5, 116.2, 116.5, 124.5, 128.3, 131.2, 134.3, 136.4 148.1, 149.5. HR-MALDI-MS (DHB): calcd for $\mathrm{C}_{48} \mathrm{H}_{21} \mathrm{~N}_{7}$ $\left(\mathrm{M}^{+}\right)$695.1853 found 695.1852.

Chromophore 10. The title compound was synthesized from 14 and 24 following the general method for Sonogashira crosscoupling. Orange solid. Yield $(144 \mathrm{mg}, 21 \%) . R_{\mathrm{f}} 0.4\left(\mathrm{SiO}_{2}\right.$; EtOAc/hexane $2: 3$ ). Mp $282{ }^{\circ} \mathrm{C}$ (dec.). IR (HATR), $\nu_{\max } / \mathrm{cm}^{-1}$ 2922, 2204 (CN), 1593, 1503, 1320, 1277, 1145, 836, 800, 735. ${ }^{1} \mathrm{H}-\mathrm{NMR}: \delta_{\mathrm{H}}\left(400 \mathrm{MHz} ; \mathrm{CD}_{2} \mathrm{Cl}_{2}\right) 7.24\left(6 \mathrm{H}, \mathrm{d},{ }^{3} J\right.$ 8.8, $\left.\mathrm{CH}_{\mathrm{Ar}}\right), 7.66$ $\left(6 \mathrm{H}, \mathrm{d},{ }^{3} J\right.$ 8.8, $\left.\mathrm{CH}_{\mathrm{Ar}}\right), 7.81\left(3 \mathrm{H}, \mathrm{d},{ }^{3} J 8.4, \mathrm{CH}_{\mathrm{Ar}}\right), 7.92\left(3 \mathrm{H}, \mathrm{dd},{ }^{3}\right.$ $J$ 8.4 $\left.{ }^{4} J 1.2, \mathrm{CH}_{\mathrm{Ar}}\right), 8.04\left(3 \mathrm{H}, \mathrm{d},{ }^{4} J 1.2, \mathrm{CH}_{\mathrm{Ar}}\right) .{ }^{13} \mathrm{C}-\mathrm{NMR}: \delta_{\mathrm{C}}(100 \mathrm{MHz}$; $\mathrm{CD}_{2} \mathrm{Cl}_{2}$ ) 85.7, 101.1, 112.5, 116.4, 116.7, 116.8, 117.2, 124.9, 132.0, 133.2, 134.3, 136.1, 136.5, 148.4. HR-MALDI-MS (DHB): calcd for $\mathrm{C}_{48} \mathrm{H}_{21} \mathrm{~N}_{7}\left(\mathrm{M}^{+}\right)$695.1853 found 695.1872.

Chromophore 11. The title compound was synthesized from 14 and 32 following the general method for Sonogashira crosscoupling. Orange solid. Yield $(160 \mathrm{mg}, 25 \%) . R_{\mathrm{f}} 0.35\left(\mathrm{SiO}_{2}\right.$; EtOAc/hexane 3:4). Mp $191{ }^{\circ} \mathrm{C}$. IR (HATR), $\nu_{\max } / \mathrm{cm}^{-1} 2925$, 2208 (CN), 1593, 1504, 1320, 1291, 834, 808, 737. ${ }^{1} \mathrm{H}-\mathrm{NMR}: \delta_{\mathrm{H}}$ (400 MHz; $\left.\mathrm{CD}_{2} \mathrm{Cl}_{2}\right) 7.18\left(6 \mathrm{H}, \mathrm{d},{ }^{3} J 8.8, \mathrm{CH}_{\mathrm{Ar}}\right), 7.31$ (3H, d, $\left.{ }^{3} J 4.0, \mathrm{Th}\right)$, $7.55\left(6 \mathrm{H}, \mathrm{d},{ }^{3} J\right.$ 8.8, $\left.\mathrm{CH}_{\mathrm{Ar}}\right), 7.62\left(3 \mathrm{H}, \mathrm{d},{ }^{3} J\right.$ 4.0, Th). ${ }^{13} \mathrm{C}-\mathrm{NMR}: \delta_{\mathrm{C}}$ (100 MHz; $\mathrm{CD}_{2} \mathrm{Cl}_{2}$ ) 81.2, 97.0, 110.4, 114.1, 117.1, 124.8, 131.2, 132.0, 133.6, 138.0, 147.9. HR-MALDI-MS (DHB): calcd for $\mathrm{C}_{39} \mathrm{H}_{18} \mathrm{~N}_{4} \mathrm{~S}_{3}$ $\left(\mathrm{M}^{+}\right) 638.0688$ found 638.0705 .

Chromophore 12. The title compound was synthesized from 14 and 33 following the general method for Sonogashira crosscoupling. Dark orange solid. Yield (111 mg, 16\%). $R_{\mathrm{f}} 0.25\left(\mathrm{SiO}_{2}\right.$; EtOAc/hexane $3: 4)$. Mp $198{ }^{\circ} \mathrm{C}$ (dec.). IR (HATR), $\nu_{\max } / \mathrm{cm}^{-1}$ 2848, 2236 (CN), 1592, 1472, 1377, 1169, 831, 728, 718. ${ }^{1} \mathrm{H}-\mathrm{NMR}$ : $\delta_{\mathrm{H}}\left(500 \mathrm{MHz} ; \mathrm{CD}_{2} \mathrm{Cl}_{2}\right) 7.19\left(6 \mathrm{H}, \mathrm{d},{ }^{3} J 9.0, \mathrm{CH}_{\mathrm{Ar}}\right), 7.59\left(6 \mathrm{H}, \mathrm{d},{ }^{3}\right.$ J 9.0, $\left.\mathrm{CH}_{\mathrm{Ar}}\right), 7.99(3 \mathrm{H}, \mathrm{s}, \mathrm{Th}) .{ }^{13} \mathrm{C}-\mathrm{NMR}: \delta_{\mathrm{C}}\left(100 \mathrm{MHz} ; \mathrm{CD}_{2} \mathrm{Cl}_{2}\right)$ 78.2, 103.1, 111.8, 111.9, 112.3, 114.9, 115.8, 124.6, 133.7, 135.5, 136.6, 148.0. HR-MALDI-MS (DHB): calcd for $\mathrm{C}_{42} \mathrm{H}_{27} \mathrm{~N}_{13}\left(\mathrm{M}^{+}\right)$ 713.2507 found 713.2532 .

\section{Acknowledgements}

This research was supported by the Czech Science Foundation (13-01061S).

\section{Notes and references}

1 (a) L. Guo and M. S. Wong, Adv. Mater., 2014, 26, 5400; (b) G. S. He, L.-S. Tan, Q. Zheng and P. N. Prasad, Chem. Rev., 2008, 108, 1245; (c) S. R. Marder, Chem. Commun., 2006, 131.

2 (a) Special issue on "Organic electronics and optoelectronics", ed. S. R. Forrest and M. E. Thompson, Chem. Rev., 2007, 107, 923; (b) Special issue on "Materials for electronics", ed. R. D. Miller and E. A. Chandross, Chem. Rev., 2010, 110, 1; (c) Special issue on "Molecular electronics - from a visionary concept towards reality”, ed. M. Mayor, Chimia, 2010, 64, 348.

3 (a) M. Pawlicki, H. A. Collins, R. G. Denning and H. L. Anderson, Angew. Chem., Int. Ed., 2009, 48, 3244; (b) F. Terenziani, C. Katan, E. Badaeva, S. Tretiak and M. Blanchard-Desce, Adv. Mater., 2008, 20, 4641.

4 (a) S. Yao and K. D. Belfield, Eur. J. Org. Chem., 2012, 3199; (b) H. M. Kim and B. R. Cho, Acc. Chem. Res., 2009, 42, 863; (c) C. Le Droumaguet, A. Sourdon, E. Genin, O. Mongin and M. Blanchard-Desce, Chem. - Asian J., 2013, 8, 2984; (d) B. Dumat, G. Bordeau, E. Faurel-Paul, F. MahuteauBetzer, N. Saettel, G. Metge, C. Fiorini-Debuisschert, F. Charra and M.-P. Teulade-Fichou, J. Am. Chem. Soc., 2013, 135, 12697; (e) S. Picard, E. Genin, G. Clermont, V. Hugues, O. Mongin and M. Blanchard-Desce, New J. Chem., 2013, 37, 3899; $(f)$ L. Zhu, W. Lv, S. Liu, H. Yan, Q. Zhao and W. Huang, Chem. Commun., 2013, 49, 10638; (g) G. Wang, X. Zhang, J. Geng, K. Li, D. Ding, K.-Y. Pu, L. Cai, Y-H. Lai and B. Liu, Chem. - Eur. J., 2012, 18, 9705; (h) Z. Yang, N. Zhao, Y. Sun, F. Miao, Y. Liu, X. Liu, Y. Zhang, W. Ai, G. Song, X. Schen, X. Yu, J. Sun and W.-Y. Wong, Chem. Commun., 2012, 48, 3442; (i) X. Zhang, X. Ren, Q.-H. Xu, K. P. Loh and Z.-K. Chen, Org. Lett., 2009, 11, 1257; $(j)$ G. Wang, X. Zhang, J. Geng, K. Li, D. Ding, K.-Y. Pu, L. Cai, Y.-H. Lai and B. Liu, Chem. - Eur. J., 2012, 18, 9705; (k) G. Wang, K.-Y. Pu, X. Zhang, K. Li, L. Wang, 
L. Cai, D. Ding, Y.-H. Lai and B. Liu, Chem. Mater., 2011, 23, 4428; ( $l$ ) O. P. Varnavski, J. C. Ostrowski, L. Sukhomlinova, R. J. Twieg, G. C. Bazan and T. Goodson III, J. Am. Chem. Soc., 2002, 124, 1736; $(m)$ W. Denk, J. H. Strickler and W. W. Webb, Science, 1990, 248, 73.

5 (a) F. Hammerer, G. Garcia, S. Chen, F. Poyer, S. Achelle, C. Fiorini-Debuisschert, M.-P. Teulade-Fichou and P. Maillard, J. Org. Chem., 2014, 79, 1406; (b) S. Achelle, P. Couleaud, P. Baldeck, M. P. Teulade-Fichou and P. Maillard, Eur. J. Org. Chem., 2011, 1271; (c) M. Gary-Bobo, Y. Mir, C. Rouxel, D. Brevet, I. Basile, M. Maynadier, O. Vaillant, O. Mognin, M. Blanchard-Desce, A. Morère, M. Garcia, J.-O. Durand and L. Raehm, Angew. Chem., Int. Ed., 2011, 50, 11425; (d) S. P. McIlroy, E. Cló, L. Nikolajsen, P. K. Frederiksen, C. B. Nielsen, K. V. Mikkelsen, K. V. Gotheft and P. O. Ogilby, J. Org. Chem., 2005, 70, 1134; (e) J. R. Starkey, A. K. Rebane, M. A. Drobizhev, F. Meng, A. Gong, A. Elliott, K. McInnerney and C. W. Spangler, Clin. Cancer Res., 2008, 14, 6564.

6 (a) A. Abbotto, L. Beverina, R. Bozio, S. Bradamante, C. Ferrante, G. A. Pagani and R. Signorini, Adv. Mater., 2000, 12, 1963; (b) F. Hao, X. Zhang, Y. Tian, H. Zhou, L. Li, J. Wu, S. Zhang, J. Yang, B. Jin, X. Tao, G. Zhou and M. Jiang, J. Mater. Chem., 2009, 19, 9163.

7 (a) D. A. Parthenopoulos and P. M. Rentzepis, Science, 1989, 245, 843; (b) B. H. Cumpston, S. P. Ananthavel, S. Barlow, D. L. Dyer, J. E. Ehrlich, L. L. Erskine, A. A. Heikal, S. M. Kuebler, I.-Y. Sandy Lee, D. McCord-Maughon, J. Qin, H. Röckel, M. Rumi, X.-L. Wu, S. R. Marder and J. W. Perry, Nature, 1999, 398, 51; (c) J. H. Strickler and W. W. Webb, Opt. Lett., 1991, 16, 1780.

8 (a) W. Zhou, S. M. Kuebler, K. L. Braun, T. Yu, J. K. Cammack, C. K. Ober, J. W. Perry and S. R. Marder, Science, 2002, 296, 1106; (b) L. Kelemen, P. Ormos and G. Vizsnyiczai, J. Eur. Opt. Soc.-Rapid, 2011, 6, 11029; (c) M. Jin, J. Xie, J.-P. Malval, A. Spangenberg, O. Soppera, D.-L. Versace, T. Leclerc, H. Pan, D. Wan, H. Pu, P. Baldeck, O. Poizat and S. Knopf, J. Mater. Chem. C, 2014, 2, 7201.

9 (a) F. Bureš, $R S C A d v$., 2014, 4, 58826; (b) P. D. Jarowski and Y. Mo, Chem. - Eur. J., 2014, 20, 17214; (c) H. Meier, Angew. Chem., Int. Ed., 2005, 44, 2482; (d) J. Y. Lee, K. S. Kim and B. J. Mhin, J. Chem. Phys., 2001, 115, 9484; (e) F. Bureš, O. Pytela, M. Kivala and F. Diederich, J. Phys. Org. Chem., 2011, 24, 274.

10 (a) F. A. Martin, C. Baudequin, C. Fiol-Petit, M. Darabantu, Y. Ramondec and N. Plé, Tetrahedron, 2014, 70, 2546; (b) Y. Jiang, Y. Wang, J. Hua, J. Tang, B. Li, S. Qian and H. Tian, Chem. Commun., 2010, 46, 4689; (c) Y. Jiang, Y. Wang, B. Wang, J. Yang, N. He, S. Qian and J. Hua, Chem. - Asian J., 2011, 6, 157; (d) S. Zeng, X. Ouyang, H. Zeng, W. Ji and Z. Ge, Dyes Pigm., 2012, 94, 290.

11 (a) C. Rouxel, C. Le Droumaguet, Y. Macé, S. Clift, O. Mongin, E. Magnier and M. Blanchard-Desce, Chem. - Eur. J., 2012, 18, 12487; (b) L. Porrès, O. Mongin, C. Katan, M. Charlot, T. Pons, J. Mertz and M. Blanchard-Desce, Org. Lett., 2004, 6, 47; (c) C. Le Droumaguet, O. Mongin, M. H. V. Werts and M. Blanchard-Desce, Chem. Commun.,
2005, 2802; (d) J. Wu, Y. Zhao, X. Li, M. Shi, F. Wu and X. Fang, New J. Chem., 2006, 30, 1098; (e) Y.-P. Tian, L. Li, J.-Z. Zhang, J.-X. Yang, H.-P. Zhou, J.-Y. Wu, P.-P. Sun, L.-M. Tao, Y.-H. Guo, C.-K. Wang, H. Xing, W.-H. Huang, X.-T. Tao and M.-H. Jiang, J. Mater. Chem., 2007, 17, 3646; $(f)$ O. Mongin, L. Porrès, C. Katan, T. Pons, J. Mertz and M. Blanchard-Desce, Tetrahedron Lett., 2003, 44, 8121; ( $g$ ) C. Huang, M. M. Sartin, N. Siegel, M. Cozzuol, Y. Zhang, J. M. Hales, S. Barlow, J. W. Perry and S. R. Marder, J. Mater. Chem., 2011, 21, 16119; (h) J. C. Collings, S.-Y. Poon, C. Le Droumaguet, M. Charlot, C. Katan, L.-O. Pålsoon, A. Beeby, J. A. Mosely, H. M. Kaiser, D. Kaufmann, W.-Y. Wong, M. Blanchard-Desce and T. B. Marder, Chem. - Eur. J., 2009, 15, 198; (i) Y.-X. Yan, X.-T. Tao, Y.-H. Sun, C.-K. Wang, G.-B. Xu, J.-X. Yang, Y. Ren, X. Zhao, Y.-Z. Wu, X.-Q. Yu and M.-H. Jiang, J. Mater. Chem., 2004, 14, 2995; (j) A. Bhaskar, G. Ramakrishna, Z. Lu, R. Twieg, J. M. Hales, D. J. Hagan, E. Van Stryland and T. Goodson III, J. Am. Chem. Soc., 2006, 128, 11840; (k) H. Xiao, C. Mei, B. Li, N. Ding, Y. Zhang and T. Wei, Dyes Pigm., 2013, 99, 1051; (l) M. Parent, O. Mongin, K. Kamada, C. Katan and M. Blanchard-Desce, Chem. Commun., 2005, 2029; (m) D. W. Brousmiche, J. M. Serin, J. M. J. Fréchet, G. S. He, T.-C. Lin, S. J. Chung and P. P. Prasad, J. Am. Chem. Soc., 2003, 125, 1448; (n) S. J. Chung, K.-S. Kim, T.-C. Lin, G. S. He, J. Swiatkiewicz and P. P. Prasad, J. Phys. Chem. B, 1999, 103, 10741; (o) V. Hrobáriková, P. Hrobárik, P. Gajdoš, I. Fitilis, M. Fakis, P. Persephonis and P. Zahradník, J. Org. Chem., 2010, 75, 3053; (p) G. Bordeau, R. Lartia, G. Metge, C. Fliorini-Debuisschert, F. Charra and M.-P. Teulade-Fichou, J. Am. Chem. Soc., 2008, 130, 16836; (q) R. Lartia, C. Allain, G. Bordeau, F. Schmidt, C. Fiorini-Debuisschert, F. Charra and M.-P. Teulade-Fichou, J. Org. Chem., 2008, 73, 1732; (r) S.-I. Kato, T. Matsumoto, M. Shigeiwa, H. Gorohmaru, S. Maeda, T. Ishi-i and S. Mataka, Chem. - Eur. J., 2006, 12, 2303; (s) Y. Jiang, Y. Wang, J. Yang, J. Hua, B. Wang, S. Qian and H. Tian, J. Polym. Sci., Part A: Polym. Chem., 2011, 49, 1830; $(t)$ J.-W. Seo, S. Y. Jang, D. Kim and H.-J. Kim, Tetrahedron, 2008, 64, 2733.

12 (a) B. Xu, H. Fang, F. Chen, H. Lu, J. He, Y. Li, Q. Chen, H. Sun and W. Tian, New J. Chem., 2009, 33, 2457; (b) T.-C. Lin, W.-L. Lin, C.-M. Wang and C.-W. Fu, Eur. J. Org. Chem., 2011, 912; (c) Z.-Q. Yan, B. Xu, Y.-J. Dong, W.-J. Tian and A.-W. Li, Dyes Pigm., 2011, 90, 269; (d) P. Wei, X. Bi, Z. Wu and Z. Xu, Org. Lett., 2005, 7, 3199.

13 (a) Y. Qian and M. Luo, Dyes Pigm., 2014, 101, 240; (b) L. Guo, K. F. Li, M. S. Wong and K. W. Cheah, Chem. Commun., 2013, 49, 3579; (c) T.-C. Lin, Q. Zheng, C.-Y. Chen, G. S. He, W.-J. Huang, A. I. Ryasnyanskiy and P. N. Prasad, Chem. Commun., 2008, 389.

14 (a) T. Kengthanomma, P. Thamyongkit, J. Gasiorowski, A. M. Ramil and N. S. Sariciftci, J. Mater. Chem. A, 2013, 1, 10524; (b) J. Zhang, J. Yu, C. He, D. Deng, Z.-G. Zhang, M. Zhang, Z. Li and Y. Li, Org. Electron., 2012, 13, 166.

15 E. Gagnon, T. Maris and J. D. Wuest, Org. Lett., 2010, 12, 404. 16 (a) K. Melánová, D. Cvejn, F. Bureš, V. Zima, J. Svoboda, L. Beneš, T. Mikysek, O. Pytela and P. Knotek, Dalton Trans., 
2014, 43, 10462; (b) J. F. Eubank, F. Nouar, R. Luebke, A. J. Cairns, L. Wojtas, M. Alkordi, T. Bosquet, M. R. Hight, J. Eckert, J. P. Embs, P. A. Georgiev and M. Eddaoudi, Angew. Chem., Int. Ed., 2012, 51, 10099; (c) D. Zhao, D. Yuan, D. Sun and H.-C. Zhou, J. Am. Chem. Soc., 2009, 131, 9186.

17 (a) N. Niammont, N. Kimpitak, G. Tumcharern, P. Rashatasakhon and M. Sukwattanasinitt, RSC Adv., 2013, 3, 25215; (b) N. Niammont, W. Siripornnoppakhun, P. Rashatasakhon and M. Sukwattanasinitt, Org. Lett., 2009, 11, 2768; (c) K. Vongnam, T. Vilaivan, M. Sukwattanasinitt and P. Rashatasakhon, J. Fluoresc., 2014, 24, 197.

18 S. Körsten and G. J. Mohr, Chem. - Eur. J., 2011, 17, 969.

19 (a) N. Niammont, N. Kimpitak, K. Wongravee, P. Rashatasakhon, K. K. Baldridge, J. S. Siegel and M. Sukwattanasinitt, Chem. Commun., 2013, 49, 780; (b) Z. Zhao, J. Liu, J. W. Y. Lam, C. Y. K. Chan, H. Qiu and B. Z. Tang, Dyes Pigm., 2011, 91, 258.

20 (a) M. Kivala and F. Diederich, Acc. Chem. Res., 2009, 42, 235; (b) M. Kivala and F. Diederich, Pure Appl. Chem., 2008, 80, 411; (c) J. Kulhánek and F. Bureš, Beilstein J. Org. Chem., 2012, 8, 25; (d) N. N. P. Moonen, R. Gist, C. Boudon, J.-P. Gisselbrecht, P. Seiler, T. Kawai, A. Kishioka, M. Gross, M. Irie and F. Diederich, Org. Biomol. Chem., 2003, 1, 2032; (e) F. Bureš, W. B. Schweizer, J. C. May, C. Boudon, J.-P. Gisselbrecht, M. Gross, I. Biaggio and F. Diederich, Chem. - Eur. J., 2007, 13, 5378; ( $f$ ) F. Bureš, W. B. Schweizer, C. Boudon, J.-P. Gisselbrecht, M. Gross and F. Diederich, Eur. J. Org. Chem., 2008, 994; (g) F. Bureš, H. Čermáková, J. Kulhánek, M. Ludwig, W. Kuznik, I. V. Kityk, T. Mikysek and A. Růžička, Eur. J. Org. Chem., 2012, 529; (h) L. Dokládalová, F. Bureš, W. Kuznik, I. V. Kityk, A. Wojciechowski, T. Mikysek, N. Almonasy, M. Ramaiyan, Z. Padělková, J. Kulhánek and M. Ludwig, Org. Biomol. Chem., 2014, 12, 5517.

21 (a) J. Yoo, S. K. Yang, M.-Y. Jeong, H. C. Ahn, S.-J. Jeon and B. R. Cho, Org. Lett., 2003, 5, 645; (b) W. J. Yang, D. Y. Kim, C. H. Kim, M.-Y. Jeong, S. K. Lee, S.-J. Jeon and B. R. Cho, Org. Lett., 2004, 6, 1389; (c) W. J. Yang, D. Y. Kim, M.-Y. Jeong, H. M. Kim, S.-J. Jeon and B. R. Cho, Chem. Commun., 2003, 2618; (d) W. J. Jang, D. Y. Kim, M.-Y. Jeong, H. M. Kim, Y. K. Lee, X. Fang, S.-J. Jeon and B. R. Cho, Chem. - Eur. J., 2005, 11, 4191; (e) B. J. Zhang and S.-J. Jeon, Chem. Phys. Lett., 2003, 377, 210; $(f)$ B. Wang, Y. Wang, J. Hua, Y. Jiang, J. Huang, S. Qian and H. Tian, Chem. - Eur. J., 2011, 17, 2647; $(g)$ E. Ripaud, Y. Olivier, P. Leriche, J. Cornil and J. Roncali, J. Phys. Chem. B, 2011, 115, 9379.

22 (a) J. Zhang, D. Deng, C. He, Y. He, M. Zhang, Z.-G. Zhang, Z. Zhang and Y. Li, Chem. Mater., 2011, 23, 817; (b) J. Jia, Y. Zhang, P. Xue, P. Zhang, X. Zhao, B. Liu and R. Lu, Dyes Pigm., 2013, 96, 407.

23 (a) Z. Fang, R. D. Webster, M. Samoc and Y.-H. Lai, RSC $A d v .$, 2013, 3, 17914; (b) M. G. Vivas, D. L. Silva, J. Malinge, M. Boujtita, R. Zaleśny, W. Bartkowiak, H. Ångren, S. Canuto,
L. De Boni, E. Ishow and C. R. Mendonca, Sci. Rep., 2014, 4, 4447; (c) P. Hrobárik, V. Hrobáriková, I. Sigmundová, P. Zahradník, M. Fakis, I. Polyzos and P. Persephonis, J. Org. Chem., 2011, 76, 8726.

24 J. Kulhánek, F. Bureš, T. Mikysek, J. Ludvík and O. Pytela, Dyes Pigm., 2011, 90, 48.

25 D. M. Johnson and P. G. Rasmussen, Macromolecules, 2000, 33, 8597.

26 J.-Y. Balandier, F. Quist, C. Amato, S. Sergueev, Y. Geerts, J. Cornil and S. Bouza-Kraoui, WO 2011/02712, 2011.

27 J. Ni, K.-J. Wei, Y. Liu, X.-C. Huang and D. Li, Cryst. Growth Des., 2010, 10, 3964.

28 H. M. S. Kumar, B. V. S. Reddy, P. T. Reddy and J. S. Yadav, Synthesis, 1999, 586.

29 Y.-P. Tian, L. Li, Y.-Z. Zhang, J.-X. Yang, H. Zhou, J. Wu, P. Sun, L. Tao, Y. Guo, C.-K. Wang, H. Xing, W. Huang, X.-T. Tao and M.-H. Jiang, J. Mater. Chem., 2007, 17, 3646.

30 (a) F. Texier-Boullet and A. Foucaud, Tetrahedron Lett., 1982, 23, 4927; (b) M. Klikar, F. Bureš, O. Pytela, T. Mikysek, Z. Padělková, A. Barsella, K. Dorkenoo and S. Achelle, New J. Chem., 2013, 37, 4230.

31 C. Lambert, W. Gaschler, E. Schmälzlin, K. Meerholz and C. Bräuchle, J. Chem. Soc., Perkin Trans. 2, 1999, 577.

32 A. A. Isse and A. Gennaro, J. Phys. Chem. B, 2010, 114, 7894. 33 (a) J. Kulhánek, F. Bureš, O. Pytela, T. Mikysek, J. Ludvík and A. Růžička, Dyes Pigm., 2010, 85, 57; (b) M.-B. S. Kirketerp, M. Å. Petersen, M. Wanko, H. Zettergren, A. Rubio, M. B. Nielsen and S. B. Nielsen, ChemPhysChem, 2010, 11, 2495.

34 J. Kulhánek, F. Bureš, J. Opršal, W. Kuznik, T. Mikysek and A. Růžička, Asian J. Org. Chem., 2013, 2, 422.

35 M. J. Frisch, G. W. Trucks, H. B. Schlegel, G. E. Scuseria, M. A. Robb, J. R. Cheeseman, G. Scalmani, V. Barone, B. Mennucci, G. A. Petersson, H. Nakatsuji, M. Caricato, X. Li, H. P. Hratchian, A. F. Izmaylov, J. Bloino, G. Zheng, J. L. Sonnenberg, M. Hada, M. Ehara, K. Toyota, R. Fukuda, J. Hasegawa, M. Ishida, T. Nakajima, Y. Honda, O. Kitao, H. Nakai, T. Vreven, J. A. Montgomery, Jr., J. E. Peralta, F. Ogliaro, M. Bearpark, J. J. Heyd, E. Brothers, K. N. Kudin, V. N. Staroverov, T. Keith, R. Kobayashi, J. Normand, K. Raghavachari, A. Rendell, J. C. Burant, S. S. Iyengar, J. Tomasi, M. Cossi, N. Rega, J. M. Millam, M. Klene, J. E. Knox, J. B. Cross, V. Bakken, C. Adamo, J. Jaramillo, R. Gomperts, R. E. Stratmann, O. Yazyev, A. J. Austin, R. Cammi, C. Pomelli, J. W. Ochterski, R. L. Martin, K. Morokuma, V. G. Zakrzewski, G. A. Voth, P. Salvador, J. J. Dannenberg, S. Dapprich, A. D. Daniels, O. Farkas, J. B. Foresman, J. V. Ortiz, J. Cioslowski and D. J. Fox, Gaussian 09, Revision D.01, Gaussian, Inc, Wallingford CT, 2013.

36 ArgusLab 4.0, Mark A. Thompson, Planaria Software LLC, Seattle, WA. http://www.arguslab.com. 